\title{
PENGARUH RELATIONSHIP QUALITY TERHADAP LOYALITAS NASABAH TABUNGAN SIKOCI PADA BANK NAGARI CABANG SOLOK
}

\author{
Beni Eka Yanti, Aminar Sutra Dewi \\ Sekolah Tinggi Ilmu Ekonomi KBP \\ beniekayanti@gmail.com
}

\begin{abstract}
The purpose of this study was to determine and analyze the influence relationship quality that consists of trust, satisfaction, perception, communication, and social cohesion on customer loyalty Savings Sikoci at Bank Nagari Branch Solok. Type of research is quantitative research. The sample size used was 100 customers Sikoci Savings in Bank Nagari Branch Solok. Data analysis technique used is in the form of research instrument test the validity and reliability test, descriptive analysis, the classical assumption test, multiple linear regression analysis, $F$ test, $t$ test and coefficient of determination. Research conducted generating trust, satisfaction, perception, communication, and social cohesion significant effect on customer loyalty Savings Sikoci at Bank Nagari Branch Solok because $t_{\text {value }}$ trust (2,006), satisfaction (2.254), perception (2,308), communications (2,056), and social cohesion (2.030) $>t$ table 1.984. The amount of influence relationship quality variable that consists of trust, satisfaction, perception, communication, and social cohesion describes customer loyalty Savings Sikoci at Bank Nagari Branch Solok was $51.1 \%$ and $48.9 \%$ explained by other variables such as quality of service, and marketing mix, etc
\end{abstract}

Keywords: Relationship Quality and Customer Loyalty.

\section{PENDAHULUAN}

Pesatnya perkembangan perekonomian saat ini telah mendorong pertumbuhan industri-industri perbankan. Hal ini menyebabkan persaingan yang ketat diantara perusahaan-perusahaan perbankan, terutama dalam hal memperoleh dan mempertahankan nasabah. Tingkat persaingan yang tinggi mengharuskan perusahaan perbankan untuk memperhatikan pentingnya elemen kualitas hubungan (relationship quality) sebagai upaya untuk mempertahankan nasabah yang ada. Untuk itu perusahaan perbankan harus memahami nasabahnya agar tetap loyal dan tidak berpindah ke pesaing. Untuk memenangkan persaingan, perusahaan perbankan harus memperhatikan kebutuhan dan keinginan para nasabah, serta berusaha memenuhi harapan mereka, sehingga mampu memberikan kepuasan kepada para nasabahnya. Disamping itu agar suatu perusahaan bisa memenangkan persaingan, maka dibutuhkan berbagai inovasi dalam pengelolaannya. Salah satu strategi yang bisa dilakukan yaitu dengan menerapkan pelayanan yang prima (service excellent) terhadap para nasabah maupun calon nasabah, sehingga nasabah memiliki hubungan emosional yang kuat dengan Bank Nagari yang akhirnya akan memunculkan sebuah loyalitas. 
Menurut Wahyu Nugroho (2005:11) loyalitas konsumen didefinisikan sebagai suatu ukuran kesetiaan dari pelanggan dalam menggunakan suatu merek produk atau merek jasa pada kurun waktu tertentu pada situasi dimana banyak pilihan produk ataupun jasa yang dapat memenuhi kebutuhannya dan pelanggan memiliki kemampuan mendapatkannya.

Loyalitas nasanah tabungan sikoci di Bank Nagari Cabang Solok yang didominasi oleh nasabah yang bekerja di lingkungan pemerintah daerah ataupun swasata tentunya berorientasi pada kemudahan dan keunggulan yang di peroleh dari tabungan sikoci. Serta kemudahan dalam transaksi keuangan juga fitur yang diberikan oleh produk tabungan sikoci. Selain itu faktor kedekatan emosional juga menjadi cara bagi Bank Nagari utuk tetap menajdi pilihan bagi nasabahnya. Tentunya untuk menjaga hal tersebut Bank Nagari Cabang Solok harus tetap menjaga hubungan dengan nasabah sehingga nasabah tidak hanya puas tetapi juga loyal terhadap Bank Nagari. Sehingga nasabah tetap memilih Bank Nagari di tengah-tengah pesatnya persaingan perbankan di Sumatera Barat.

Pelayanan yang diberikan Bank Nagari terhadap nasabah harus dilandasi keinginan tulus untuk menciptakan hubungan baik dengan nasabah. Sudah semestinya Bank Nagari tampil dan berperan layaknya seorang sahabat sehingga nasabah akan selalu datang karena telah terjalin relationship yang kuat. Bank Nagari sebagai sahabat tentu memberikan solusi yang tepat dan tuntas terhadap ragam kebutuhan nasabah. Jalinan relationship yang sedemikian kuat tentu akan memberikan dampak positif kepada seluruh pemangku kepentingan (stakeholder) dan juga nasabah, dimana hal ini akan bermuara pada pertumbuhan kedua belah pihak secara berkualitas dan berkesinambungan dari waktu ke waktu. Membina relationship dengan nasabah adalah sangat penting dalam memelihara kelangsungan pertumbuhan sebuah perusahaan.

PT. Bank Pembangunan Daerah Sumatera Barat atau yang lebih dikenal dengan panggilan Bank Nagari merupakan salah satu industri perbankan di Sumatera Barat yang juga menerapkan pentingnya memberikan pelayanan yang terbaik bagi setiap nasabahnya dan selalu berusaha memahami kebutuhan dan keinginan nasabahnya, dengan menawarkan berbagai macam produk-produk perbankan, Bank Nagari berusaha untuk memuaskan dan memberi kemudahan pada setiap nasabahnya dalam melakukan transaksi-transaksi perbankan. Salah satu produk Bank Nagari yang paling umum dan memiliki jumlah nasabah yang besar adalah produk tabungan Sikoci. Tabungan Sikoci adalah tabungan dalam mata uang rupiah yang menawarkan berbagai keuntungan dalam bertransaksi. Produk tabungan yang paling dapat diandalkan dan memiliki jumlah nasabah terbesar adalah sikoci, dapat dilihat dari tabel dibawah ini.

\section{Tabel 1}

Jumlah Nasabah Tabungan Sikoci Pada Bank Nagari Cabang Solok Periode April 2016

\begin{tabular}{|c|c|}
\hline Tahun & Jumlah Nasabah \\
\hline 2013 & 12.905 \\
\hline 2014 & 15.786 \\
\hline 2015 & 17.018 \\
\hline
\end{tabular}

Sumber: Rekapitulasi Tabungan Bank Nagari Cabang Solok.

Pada Tabel 1 dapat dilihat bahwa Bank Nagari memiliki jumlah nasabah yang terus meningkat pada setiap tahunnya. Salah satu cara yang dilakukan oleh 
Bank Nagari dalam usaha mempertahankan loyalitas nasabahnya adalah dengan tetap membina kualitas hubungan (relationship quality) yang baik dengan setiap nasabah, dimana nasabah diajak untuk membangun sebuah hubungan yang lebih dekat dengan menciptakan komunikasi dua arah sehingga dapat menimbulkan kepercayaan, kepuasan, bahkan sebuah ikatan sosial yang pada akhirnya dapat menimbulkan sebuah komitmen antara nasabah dan perusahaan perbankan.

Dengan memberikan hubungan yang berkualitas tinggi kepada nasabah maka nasabah mendapat kepuasan yang berujung pada loyalitasnya pada suatu bank. Loyalitas dapat diartikan sebagai kesetiaan, yaitu kesetiaan seseorang terhadap suatu objek. Sedangkan konsumen adalah seseorang yang terbiasa membeli suatu produk. Kebiasaan tersebut terbentuk melalui pembelian dan interaksi yang sering dilakukan selama periode waktu tertentu (Griffin, 2003:31). Loyalitas konsumen telah menjadi salah satu impian dari setiap perusahaan dan menjadi tujuan strategis yang paling penting dari suatu perusahaan dalam kurun waktu belakangan ini.

Istilah kualitas hubungan (relationship quality) berarti kualitas dipersepsikan berdasarkan kehangatan suatu hubungan (Kasali, dalam Chan, 2003:241). Dengan adanya kualitas hubungan yang tinggi maka nasabah dapat mengandalkan integritas seorang penyedia jasa dan mempunyai keyakinan terhadap performance seorang penyedia jasa di masa yang akan datang, karena di masa lalu telah memuaskan secara konsisten.

Menurut Lovelock, Patterson dan Walker dalam Tjiptono (2000:94) kualitas hubungan (relationship quality) ini di pengaruhi oleh beberapa faktor seperti (1) kepercayaan (trust), (2) kepuasan terhadap produk dan jasa sebelumnya, (3) persepsi terhadap nilai, (4) efektivitas komunikasi, (5) ikatan sosial/keakraban. Faktor-faktor inilah yang memberikan konsekuensi terhadap niat menggunakan produk secara terus menerus dan memiliki hubungan dengan loyalitas Bank Nagari sebagai salah satu perusahaan perbankan di Sumatera Barat, Jakarta, Bandung, dan Pekanbaru selalu berusaha agar para nasabah merasa puas dan membangkitkan rasa untuk tetap berkomitmen dengan perusahaan dalam jangka waktu yang lama.

Nasabah yang setia adalah asset perusahaan perbankan, oleh sebab itu perusahaan perbankan harus mampu membina hubungan yang lebih baik dengan setiap nasabahnya yaitu dengan membangun loyalitas nasabah serta menjaga dan mempertahankan agar tidak berpaling ke perusahaan perbankan lain.

Berdasarkan uraian diatas, penulis tertarik untuk mengadakan penelitian dengan judul "Pengaruh Relationship Quality Terhadap Loyalitas Nasabah Tabungan Sikoci Pada Bank Nagari Cabang Solok”.

Perumusan Masalah

Berdasarkan latar belakang masalah yang telah dikemukakan di atas, maka perumusan masalah yang akan penulis bahas dalam penelitian ini adalah sebagai berikut:

1. Apakah kepercayaan berpengaruh terhadap loyalitas nasabah tabungan sikoci pada Bank Nagari Cabang Solok?

2. Apakah kepuasan berpengaruh terhadap loyalitas nasabah tabungan sikoci pada Bank Nagari Cabang Solok.

3. Apakah persepsi berpengaruh terhadap loyalitas nasabah tabungan sikoci pada Bank Nagari Cabang Solok. 
4. Apakah komunikasi berpengaruh terhadap loyalitas nasabah tabungan sikoci pada Bank Nagari Cabang Solok.

5. Apakah ikatan sosial/persahabatan berpengaruh terhadap loyalitas nasabah tabungan sikoci pada Bank Nagari Cabang Solok.

\section{TINJAUAN PUSTAKA}

Loyalitas telah diakui sebagai faktor dominan yang mempengaruhi keberhasilan bisnis saat ini, karena loyalitas konsumen (customer loyalty) telah menjadi tujuan strategis yang paling dari perusahaan dalam kurun waktu belakangan ini. Dalam perusahaan perbankan, nasabah yang loyal dapat mengingkatkan keuntungan bank, karena keuntungan pokok perbangkan adalah dari selisih bunga simpanan dengan bunga kredit atau pinjaman dari nasabah (Kasmir, 2007:136) Maka, nasabah yang konsisten melakukan transaksi perbangkan dalam suatu perushaan perbangkan dalam suatu perusahaan perbangkan dalam kurun waktu yang panjang atau memberikan keuntungan yang besar kepada perusahaan perbangkan tersebut.

Menurut Griffin dalam Hurriyati (2005:130), konsumen yang loyal memiliki karektistik sebagai berikut:

1. Melakukan pembelian secara teratur.

2. Membeli atau menggunakan di luar lini produk /jasa.

3. Merekomendasikan kepada orang lain.

4. Menunjukan kekebalan dari daya tarik produk sejenis dari pesaing.

Kualitas hubungan menurut Kumar. Scheer dan Steenkamp dalam Farida Jasfar (2002:19) bekaitan dengan hal-hal yang mencakup masalah konflik. Kepercayaan, komitmen dan kesinambungan hubungan di masa mendatang. Kualitas hubungan yang baik akan menurunkan level konflik dan sebaliknya memperbesar kepercayaan, komitmen, berlanjutnya hubungan jangka panjang dan kelanjutan investasi.

Relationship Quality menurut Huang (2012) adalah serangkaian episode interaksi perusahaan yang terjadi antara dua belah pihak dengan konsumen dalam rentang waktu tertentu untuk menjalin hubungan dengan kualitas yang mencapai satu tujuan bersama.

Menurut Lovelock, Patterson dan Walker dalam Tjiptono (2000:94) kesuksesan tersebut dipengaruhi oleh beberapa variabel yaitu:

a. Kepercayaan

Kepercayaan secara umum dipandang sebagai unsur mendasar bagi keberhasilan suatu hubungan. Tanpa adanya kepercayaan suatu hubungan tidak akan bertahan dalam jangka waktu yang panjang. Kepercayaan didefenisikan sebagai kesediaan untuk bersandar pada mitra bisnis yang dipercayai. Pengertian kepercayaan dalam pemasaran jasa lebih menekankan pada sikap individu yang mengacu kepada keyakinan konsumen atas kualitas dan keterandalan jasa yang di terimanya.

Kepercayaan timbul dari suatu proses yang lama sampai kedua belah pihak saling mempercayai. Apabila kepercayaan sudah terjalin diantara konsumen dan perusahaan, maka usaha untuk membinanya tidaklah terlalu sulit. 


\section{b. Kepuasan}

Perilaku setelah pembelian akan menimbulkan sikap puas atau tidak puas dari konsumen. Kepuasan konsumen terhadap produk dan jasa adalah tingkat perasaan dimana seseorang menyatakan hasil perbandingan atas kinerja produk atau jasa yang diterima dan diharapkannya (Kotler, dalam Fandy Tjiptono, 2003:131).

Menurut Kotler (2005:70), kepuasan adalah perasaan senang atau kecewa seseorang yang muncul setelah membandingkan antara kinerja (hasil) produk yang dipikirkan terhadap kinerja atau hasil yang di harapkan. Jika kinerja berada di bawah harapan, konsumen tidak puas. Jika kinerja memenuhi harapan, maka konsumen amat puas atau amat senang. Dengan memahami tingkat kepuasam konsumen terhdap pelayanan yang diberikan, maka perusahaan dapat mengetahui kesenjangan antara yang dilakukan perusahaan dan yang konsumen butuhkan, sehingga perusahaan dapat menentukan langkah yang tepat untuk melakukan perbaikan di masa mendatang.

c. Persepsi

Persepsi konsumen didefinisikan sebagai makna yang kita pertalikan berdasarkan pengalaman masa lalu dan ransangan-ransangan yang diterima melalui panca indera (Stanton, dalam Boyd, 2001:264)

Menurut Hill dalam Tjiptono (2000:116), persepsi adalah pandangan terhadap pelayanan yang telah diterima individu. Masing-masing individu memiliki persepsi yang berbeda-berbeda karena mereka menerima, mengorganisasikan dan menerjemahkan informasi dengan cara yang berbedabeda.

d. Komunikasi

Komunikasi adalah suatu proses pertukaran informasi antara individu ataupun konsumen melalui suatu system yang lazim (biasa), baik dengan simbol-simbol, sinyal-sinyal, maupun perilaku atau tindakan (Purwanto, 2003:3). Informasi yang didapatkan konsumen biasanya akan berhubungan dengan keputusan yang diambil konsumen untuk berkunjung atau mengambil keputusan untuk memilih.

Komunikasi bisnis adalah suatu bentuk hubungan antara komunikator dengan komunikan dimana terdapat adanya pertukatan ide, informasi, pesan, dan konsep yang berkaitan dengan pencapaiaan serangkaian tujuan komersial. Kegiatan komunikasi dalam bisnis secara sederhana tidak hanya menyampaikan informasi, tetapi juga mengandung unsur persuasi agar orang lain bersedia menerima pemahaman dan pengaruh, serta mau melaksanakan suatu perintah atau bujukan.

e. Ikatan sosial atau persahabatan

Ikatan sosial atau persahabatan akan membangun hubungn yang lebih kuat dengan konsumen dan masyrakat. Ikatan sosial persahabtan adalah hal yang timbul akibat interaksi antara karyawan dengan onsumen (Morgan, dalam Fafida. Jasfar, 2002:23). Melalui ikatan ini perusahaan berusaha memuaskan konsumen dan selalu melakukan yang terbaik demi kepentingan konsumen dan masyarakat untuk jangka panjang.

Ikatan sosial atau persahabatan adalah suatu kebutuhan member dan menerima suatu perhatian dari untuk konsumen dan masyarakat kebutuhan ini 
antara lain hubungan antara konsumen dengan penjual, hubungan antara karyawan dengan masyarakat sekitar.

Berdasarkan perumusan masalah yang telah dikemukakan, maka hipotesis penelitian adalah sebagai berikut:

a. H1 = Diduga kepercayaan berpengaruh positif dan signifikan terhadap loyalitas nasabah.

b. $\mathrm{H} 2$ = Diduga kepuasan berpengaruh positif dan signifikan terhadap loyalitas nasabah.

c. H3 = Diduga persepsi berpengaruh positif dan signifikan terhadap loyalitas nasabah.

d. H4 = Diduga komunikasi berpengaruh positif dan signifikan terhadap loyalitas nasabah.

e. H5 = Diduga ikatan sosial berpengaruh positif dan signifikan terhadap loyalitas nasabah.

\section{METODE PENELITIAN}

Jenis penelitian yang dilakukan adalah penelitian kuantitatif. Banyaknya sampel yang digunakan adalah 100 orang nasabah Tabungan Sikoci pada Bank Nagari Cabang Solok. Teknik analisis data yang digunakan yaitu uji instrumen penelitian dalam bentuk uji validitas dan uji reliabilitas, analisis deskriptif, uji asumsi klasik, analisis persamaan regresi linier berganda, uji $\mathrm{F}$, uji $\mathrm{t}$ dan analisis koefisien determinasi.

\section{HASIL PENELITIAN}

\section{a. Analisa Regresi Linier Berganda}

Hasil pengujian persamaan regresi linier berganda untuk pengaruh kepercayaan, kepuasan, persepsi, komunikasi dan ikatan sosial terhadap loyalitas nasabah Tabungan Sikoci pada Bank Nagari Cabang Solok dikemukakan pada tabel 2.

Tabel 2

Hasil Pengujian Persamaan Regresi

\begin{tabular}{|c|l|c|}
\hline No. & \multicolumn{1}{|c|}{ Model } & Regresi \\
\hline 1. & Konstanta & 0,884 \\
\hline 2. & Kepercayaan & 0,162 \\
\hline 3. & Kepuasan & 0,197 \\
\hline 4. & Persepsi & 0,215 \\
\hline 5. & Komunikasi & 0,211 \\
\hline 6. & Ikatan Sosial & 0,184 \\
\hline
\end{tabular}

Sumber: Hasil pengolahan data, tahun 2017.

Berdasarkan tabel 2 maka bentuk persamaan regresi untuk pengaruh kepercayaan, kepuasan, persepsi, komunikasi dan ikatan sosial terhadap loyalitas nasabah Tabungan Sikoci pada Bank Nagari Cabang Solok adalah sebagai berikut:

$$
Y=0,884+0,162 X_{1}+0,197 X_{2}+0,215 X_{3}+0,211 X_{4}+0,184 X_{5}+e
$$

Interpretasi dari persamaan regresi linier berganda yang dihasilkan adalah sebagai berikut: 
a. Nilai konstanta yang dihasilkan adalah 0,884. Maksudnya adalah jika kepercayaan, kepuasan, persepsi, komunikasi dan ikatan sosial tidak mengalami perubahan atau nilai $\mathrm{X}_{1}, \mathrm{X}_{2}, \mathrm{X}_{3}, \mathrm{X}_{4}, \mathrm{X}_{5}=0$, maka loyalitas nasabah Tabungan Sikoci pada Bank Nagari Cabang Solok tetap mengalami peningkatan.

b. Nilai koefisien regresi yang dihasilkan untuk kepercayaan adalah 0,162. Maksudnya adalah setiap peningkatan kepercayaan mengakibatkan peningkatan loyalitas nasabah Tabungan Sikoci pada Bank Nagari Cabang Solok.

c. Nilai koefisien regresi yang dihasilkan untuk kepuasan adalah 0,197. Maksudnya adalah setiap peningkatan kepuasan mengakibatkan peningkatan loyalitas nasabah Tabungan Sikoci pada Bank Nagari Cabang Solok.

d. Nilai koefisien regresi yang dihasilkan untuk persepsi adalah 0,215. Maksudnya adalah setiap peningkatan persepsi mengakibatkan peningkatan loyalitas nasabah Tabungan Sikoci pada Bank Nagari Cabang Solok.

e. Nilai koefisien regresi yang dihasilkan untuk komunikasi adalah 0,211. Maksudnya adalah setiap peningkatan komunikasi mengakibatkan peningkatan loyalitas nasabah Tabungan Sikoci pada Bank Nagari Cabang Solok.

f. Nilai koefisien regresi yang dihasilkan untuk ikatan sosial adalah 0,184. Maksudnya adalah setiap peningkatan ikatan sosial mengakibatkan peningkatan loyalitas nasabah Tabungan Sikoci pada Bank Nagari Cabang Solok.

\section{b. Uji F}

Hasil uji F untuk pengaruh kepercayaan, kepuasan, persepsi, komunikasi dan ikatan sosial secara bersama-sama terhadap loyalitas nasabah Tabungan Sikoci pada Bank Nagari Cabang Solok dikemukakan pada tabel 3.

\section{Tabel 3}

\section{Hasil Uji F}

\begin{tabular}{|c|c|c|c|c|c|}
\hline Model & F Hitung & F Tabel & Sig. & $\alpha$ & Keterangan \\
\hline $\begin{array}{l}\text { Kepercayaan, kepuasan, persepsi, } \\
\text { komunikasi dan ikatan sosial } \\
\text { terhadap loyalitas nasabah } \\
\text { Tabungan Sikoci pada Bank } \\
\text { Nagari Cabang Solok }\end{array}$ & 21,678 & 2,31 & 0,000 & 0,05 & Ha diterima \\
\hline
\end{tabular}

Sumber: Hasil pengolahan data, tahun 2017.

Berdasarkan tabel 3 maka interprestasi dari hasil uji $\mathrm{F}$ adalah pengaruh kepercayaan, kepuasan, persepsi, komunikasi dan ikatan sosial secara bersamasama terhadap loyalitas nasabah Tabungan Sikoci pada Bank Nagari Cabang Solok adalah signifikan. Hal ini terlihat dari nilai $\mathrm{F}_{\text {hitung }} 21,678>\mathrm{F}_{\text {tabel }} 2,31$ dan nilai signifikan $0,000<$ level of significant 0,05 .

\section{c. Uji t}

Hasil uji t untuk pengaruh kepercayaan, kepuasan, persepsi, komunikasi dan ikatan sosial terhadap loyalitas nasabah Tabungan Sikoci pada Bank Nagari Cabang Solok dikemukakan pada tabel 4. 
Tabel 4

Hasil Uji t

\begin{tabular}{|c|l|c|c|c|c|l|}
\hline No. & \multicolumn{1}{|c|}{ Model } & t Hitung & t Tabel & Sig. & $\boldsymbol{\alpha}$ & Keterangan \\
\hline 1. & Kepercayaan - Loyalitas & 2,006 & 1,984 & 0,048 & 0,05 & Ha diterima \\
\hline 2. & Kepuasan - Loyalitas & 2,254 & 1,984 & 0,026 & 0,05 & Ha diterima \\
\hline 3. & Persepsi - Loyalitas & 2,308 & 1,984 & 0,023 & 0,05 & Ha diterima \\
\hline 4. & Komunikasi - Loyalitas & 2,056 & 1,984 & 0,043 & 0,05 & Ha diterima \\
\hline 5. & Ikatan Sosial - Loyalitas & 2,030 & 1,984 & 0,045 & 0,05 & Ha diterima \\
\hline
\end{tabular}

Sumber: Hasil pengolahan data, tahun 2017. berikut:

Berdasarkan tabel 4 maka interprestasi dari hasil uji t adalah sebagai

1. Pengaruh kepercayaan terhadap loyalitas nasabah Tabungan Sikoci pada Bank Nagari Cabang Solok adalah signifikan. Hal ini terlihat dari nilai $\mathrm{t}_{\text {hitung }} 2,006>$ $\mathrm{t}$ tabel 1,984 dan nilai signifikan $0,048<$ level of significant 0,05 artinya kepercayaan mempunyai pengaruh yang signifikan terhadap loyalitas nasabah Tabungan Sikoci pada Bank Nagari Cabang Solok.

2. Pengaruh kepuasan terhadap loyalitas nasabah Tabungan Sikoci pada Bank Nagari Cabang Solok adalah signifikan. Hal ini terlihat dari nilai $t_{\text {hitung }} 2,254>$ $\mathrm{t}$ tabel 1,984 dan nilai signifikan $0,026<$ level of significant 0,05 artinya kepuasan mempunyai pengaruh yang signifikan terhadap loyalitas nasabah Tabungan Sikoci pada Bank Nagari Cabang Solok.

3. Pengaruh persepsi terhadap loyalitas nasabah Tabungan Sikoci pada Bank Nagari Cabang Solok adalah signifikan. Hal ini terlihat dari nilai $t_{\text {hitung }} 2,308>$ $t_{\text {tabel }} 1,984$ dan nilai signifikan $0,023<$ level of significant 0,05 artinya persepsi mempunyai pengaruh yang signifikan terhadap loyalitas nasabah Tabungan Sikoci pada Bank Nagari Cabang Solok.

4. Pengaruh komunikasi terhadap loyalitas nasabah Tabungan Sikoci pada Bank Nagari Cabang Solok adalah signifikan. Hal ini terlihat dari nilai $t_{\text {hitung }} 2,056>$ $\mathrm{t}$ tabel 1,984 dan nilai signifikan $0,043<$ level of significant 0,05 artinya komunikasi mempunyai pengaruh yang signifikan terhadap loyalitas nasabah Tabungan Sikoci pada Bank Nagari Cabang Solok.

5. Pengaruh ikatan sosial terhadap loyalitas nasabah Tabungan Sikoci pada Bank Nagari Cabang Solok adalah signifikan. Hal ini terlihat dari nilai $t_{\text {hitung }} 2,030>$ $\mathrm{t}$ tabel 1,984 dan nilai signifikan 0,045 < level of significant 0,05 artinya ikatan sosial mempunyai pengaruh yang signifikan terhadap loyalitas nasabah Tabungan Sikoci pada Bank Nagari Cabang Solok.

\section{d. Analisis Koefisien Determinasi $\left(\mathbf{R}^{2}\right)$}

Untuk mengetahui besarnya pengaruh kepercayaan, kepuasan, persepsi, komunikasi dan ikatan sosial terhadap loyalitas nasabah Tabungan Sikoci pada Bank Nagari Cabang Solok, maka dilakukanlah pengujian statistik dengan melakukan uji koefisien determinasi dengan hasil seperti yang dikemukakan pada tabel 5. 


\section{Tabel 5}

Hasil Uji Koefisien Determinasi

\begin{tabular}{|l|c|}
\hline \multicolumn{1}{|c|}{ Model } & R Square \\
\hline $\begin{array}{l}\text { Kepercayaan, kepuasan, persepsi, komunikasi dan ikatan sosial } \\
\text { terhadap loyalitas nasabah Tabungan Sikoci pada Bank Nagari } \\
\text { Cabang Solok }\end{array}$ & 0,511 \\
\hline
\end{tabular}

Sumber: Hasil pengolahan data, tahun 2017.

Berdasarkan tabel 4.4. dihasilkan nilai koefisien determinasi adalah 0,511 berarti besarnya pengaruh kepercayaan, kepuasan, persepsi, komunikasi dan ikatan sosial terhadap loyalitas nasabah Tabungan Sikoci pada Bank Nagari Cabang Solok adalah 51,1\% sedangkan sisanya $48,9 \%$ dipengaruhi variabel lainnya selain model yang diteliti, seperti kualitas pelayanan, bauran pemasaran, dan lain-lain.

\section{Pembahasan}

Kualitas hubungan (relationship quality) yang terdiri dari variabel kepercayaan $\left(\mathrm{X}_{1}\right)$, kepuasan $\left(\mathrm{X}_{2}\right)$, persepsi $\left(\mathrm{X}_{3}\right)$, komunikasi $\left(\mathrm{X}_{4}\right)$ dan ikatan sosial $\left(\mathrm{X}_{5}\right)$, secara bersama-sama berpengaruh secara signifikan terhadap loyalitas nasabah Tabungan Sikoci pada Bank Nagari Cabang Solok karena nilai $F$ hitung $21,678>F_{\text {tabel }} 2,31$ dan nilai signifikan $0,000<$ level of significant 0,05 .

Variabel kepercayaan berpengaruh signifikan terhadap loyalitas nasabah Tabungan Sikoci Bank Nagari Cabang Solok karena nilai $t$ hitung 2,006 $>\mathrm{t}$ tabel 1,984 dan nilai signifikan $0,048<$ level of significant 0,05 . Hal ini berarti Bank Nagari Cabang Solok besertas seluruh karyawannya tidak hanya mempertahankan reputasi dan kualitas produk yang telah ada, tetapi juga harus meningkatkan serta menciptakan reputasi yang semakin baik dan produk-produk yang semakin berkualitas demi terciptanya kepercayaan yang tinggi dari setiap nasabahnya. Produk-produk yang dihasilkan oleh Bank Nagari berkualitas tinggi sehingga menimbulkan keyakinan untuk terus menjadi nasabahnya. Untuk meningkatkan kepercayaan nasabah kepada Bank Nagari Cabang Solok seluruh karyawan harus memberikan pelayanan yang optimal, pada akhitnya juga akan mampu meningkatkan image bank, sehingga cita bank dimata nasabah terus meningkat pula. Dengan citra yang terpancar dari setiap karyawan, kepercayaan nasabah akan semakin mengautakan Bank Nagari artinya citra positif menumbuhkan kepercayaan (citra pelayanan pimpinan cabang bijaksana, citra pelayanan customer service yang handal, citra pelayanan satpam siaga. Dengan demikian citra yang baik membuat segala yang dilakukan bank akan dianggap baik pula di mata nasabah, artinya nasabah bertambah loyal kepada bank.

Variabel kepuasan berpengaruh signifikan terhadap loyalitas nasabah Tabungan Sikoci pada Bank Nagari Cabang Solok karena nilai $t_{\text {hitung }} 2,254>t_{\text {tabel }}$ 1,984 dan nilai signifikan 0,026 < level of significant 0,05 . Dengan memahami tingkat kepuasan nasabah terhadap pelayanan yang diberikan, maka Bank Nagari Cabang Solok dapat mengetahui kesenjangan antara yang dilakukan bank dan yang nasabah butuhkan, sehingga bank dapat menentukan langkah yang tepat untuk melakukan perbaikan di masa mendatang. Bank Nagari Cabang Solok dapat lebih meningkatkan kinerja dengan cara menciptakan produk-produk yang semakin berkualitas dan dapat menjaga atau mempertahankan nama baik perusahaan di mata nasabah dan masyarakat luas demi terciptanya kepercayaan yang tinggi dari setiap nasbahnya sehingga tercpta kepuasan nasabah yang dapat 
dipertahankan. Dengan pelayanan yang berkualitas, maka nasabah akan merasa puas sehingga akan mempertahankan dan meningkatkan loyalitasnya. Nasabah yang mempunyai loyalitas yang tinggi akan senantiasa menggunakan produk dan jasa yang disediakan perusahaan, tidak akan terpengaruh jasa yang ditawarkan pihak lain, dan ketika terdapat hal-hal yang tidak mereka sukai akan memberitahukan kepada penyedia jasa dan tidak memberitahukannya kepada orang lain.

Variabel persepsi berpengaruh signifikan terhadap loyalitas nasabah Tabungan Sikoci Bank Nagari Cabang Solok karena nilai t hitung 2,308 > t tabel 1,984 dan nilai signifikan 0,023 < level of significant 0,05. Untuk itu Bank Nagari Cabang Solok perlu mengkaji ulang dan menemukan cara-cara baru untuk menciptakan kinerja yang baik dan berkualitas yang akan diberikajn kepada nasabah, agar nasabah mendapatkan kesenangan, kenyamanan juga kepuasan ketika melakukan transaksi-transaksi perbankan di Bank Nagari Cabang Solok. Satu hal yang bisa dijadikan pedoman dalam hal ini, yaitu "jangan janjikan apa yang tidak bisa diberikan, tetapi berikahn lebih dari yang dijanjikan". Selalu berikan yang terbaik, jangan biarkan nasabah meninggalkan Bank Nagari Cabang Solok sebelum terpenuhi semua haknya, lakukan dengan professional.

Variabel komunikasi berpengaruh signifikan terhadap loyalitas nasabah Tabungan Sikoci pada Bank Nagari Cabang Solok karena nilai $t_{\text {hitung }} 2,056>t$ tabel 1,984 dan nilai signifikan $0,043<$ level of significant 0,05 . Maka untuk lebih meningkatkan loyalitas nasabah pada Bank Nagari Cabang Solok, pihak bank perlu memperhatikan kualitas hubungan (relationship quality) dengan tidak melupakan dan mengecewakan hubungan yang sudah terjalin dengan nasabah lama dan bersikap lebih ramah dan bersahabat dengan nasabah baru. Diharapkan pihak Bank Nagari Cabang Solok beserta seluruh karyawannya tidak hanya dapat melayani nasabah dengan menjelaskan suatu peoduk kepada nasabah dengan jelas, sehingga dapat dipahamai dan tidak hanya mengkonfirmasikan informasi terkini tentang produk kepada nasabah, tetapi pihak bank juga harus dapat meningkatkan komunikasi kepada nasabah dengan cara meningkatkan atau memperbaharui pelayanannya dengan menerapkan standar pelayanan citra secara konsisten, dan memberikan tanggapan atas komplain nasabah dengan jawaban terbaik yang memberikan solusi tuntas yang dapat dipahami oleh nasabah, bukan jawaban termudah yang dapat diucapkan oleh karyawan yang melayani komplain, memberikan penjelasan dengan jelas dan benar.

Variabel ikatan sosial berpengaruh signifikan terhadap loyalitas nasabah Tabungan Sikoci pada Bank Nagari Cabang Solok karena nilai $t_{\text {hitung }} 2,030>t_{\text {tabel }}$ 1,984 dan nilai signifikan 0,045 < level of significant 0,05. Untuk itu pihak Bank Nagari diharapkan dapat merencanakan juga melaksanakan suatu program untuk mempertingi ikatan sosial antara bank dengan nasabah. Hal ini dapat terwujud salah satunya dengan cara membuat acara-acara keakraban, member reward kepada nasabah keitiak hari-hari besar, meningkatkan pelayanan yang bersahabat serta selalu menjalin dan mejaga hubungan baik kepada setiap nasabah sehingga nasabah dapat merasakan suatu ikatan yang erat dengan bank. 


\section{SIMPULAN}

1. Kepercayaan berpengaruh signifikan terhadap loyalitas nasabah Tabungan Sikoci pada Bank Nagari Cabang Solok karena nilai $\mathrm{t}_{\text {hitung }} 2,006>\mathrm{t}$ tabel 1,984 dan nilai signifikan $0,048<$ level of significant 0,05 .

2. Kepuasan berpengaruh signifikan terhadap loyalitas nasabah Tabungan Sikoci pada Bank Nagari Cabang Solok karena nilai $t$ hitung 2,254 $>\mathrm{t}$ tabel 1,984 dan nilai signifikan $0,026<$ level of significant 0,05 .

3. Persepsi berpengaruh signifikan terhadap loyalitas nasabah Tabungan Sikoci pada Bank Nagari Cabang Solok karena nilai $t$ hitung 2,308 $>\mathrm{t}$ tabel 1,984 dan nilai signifikan $0,023<$ level of significant 0,05 .

4. Komunikasi berpengaruh signifikan terhadap loyalitas nasabah Tabungan Sikoci pada Bank Nagari Cabang Solok karena nilai $t$ hitung 2,056 $>\mathrm{t}$ tabel 1,984 dan nilai signifikan $0,043<$ level of significant 0,05 .

5. Ikatan sosial berpengaruh signifikan terhadap loyalitas nasabah Tabungan Sikoci pada Bank Nagari Cabang Solok karena nilai $t$ hitung 2,030 $>t_{\text {tabel }} 1,984$ dan nilai signifikan $0,045<$ level of significant 0,05 .

\section{DAFTAR PUSTAKA}

Arikunto, Suharsimi. 2010. Prosedur Penelitian Suatu Pendekatan Praktek. Jakarta: PT. Rineka Cipta.

Aziz, N. (2019). Pengaruh Komunikasi Efektif Terhadap Kepuasan Pelayanan Rumah Sakit Islam Siti Rahmah Padang. https://doi.org/10.17605/OSF.IO/T2H7Y

Aziz, N. (2019). Pengaruh Kualitas Layanan Terhadap Kepuasan Nasabah SMS Banking Pada Bank Nagari Cabang Pembantu RSUP DR M Djamil Padang. https://doi.org/10.17605/OSF.IO/S3JVG

Boyd, Happer W, dkk. 2001. Manajemen Pemasaran. Edisi Kedua, Jakarta: Erlangga.

Chan, Syarifuddin. 2003. Relationship Marketing: Inovasi pemasaran yang Membuat Pelanggan Bertekuk Lutut. Jakarta: PT.Gramedia Pustaka Utama.

Fernandes, Y. D., \& Marlius, D. (2018). Peranan Customer Service Dalam Meningkatkan Pelayanan Kepada Nasabah Pada PT. Bank Pembangunan Daerah Sumatera Barat Cabang Utama Padang. https://doi.org/10.31227/osf.io/wrh3p

Fernos, J., \& Putra, Y. E. (2019). Analisa Pengaruh Kualitas Pelayanan Terhadap Kepuasan Nasabah Pada PT. Bank Mega Syari'ah Padang. https://doi.org/10.31219/osf.io/y2baf

Grifin, Jill. 2005. Customer Loyalty: Memumbuhkan dan Mempertahankan Kesetiaan Pelanggan. Jakarta: Erlangga. 
Jasfar, Farida. 2002. Kualitas Hubungan (Relationship Quality) dalam Jasa Penjualan. Jurnal Riset Ekonomi dan Manajemen Volume 2 No. 3Setember 2002.

Karsono, Nurul Hudha. 2006. Pengaruh Mamfaat Reaksional dan KualitasHubunganTerhadap Kesetian dan Komunikasi Lisan Pelanggan, Jurnal Bisnis Manajemen, Volume 6, No. 1.2006:97-120.

Kasmir. 2007. Bank dan Lembaga Keuangan Lainnya. Edisi Keenam. Jakarta: PT. Raja Grafindo Persada.

Kotler,Philip. 2005. Manajemen Pemasaran. Edisi Kesebelas, Jilid Pertama, Jakarta: Selemba Empat.

Kuncoro, Mudrajat. 2003. Metode Riset untuk Bisnis dan Ekonomi. Jakarta: Erlangga.

Lupiyoadi, Rambat. 2001. Manajemen Pemasaran Jasa: Teori dan Praktek. Edisi Pertama, Jakarta: Selemba Empat.

Marlius, D. (2018). Loyalitas Nasabah Bank Nagari Syariah Cabang Bukittinggi Dilihat Dari Kualitas Pelayanan. Jurnal Pundi. Volume 1. No. 3. Hal.1222. https://doi.org/10.31575/jp.v1i3.60

Marlius, D. (2018). Pengaruh Dimensi Kualitas Pelayanan Website Akademik Terhadap Kepuasan Mahasiswa Pada STIE “KBP”. Jurnal Ipteks Terapan. $\begin{array}{lllll}\text { Volume } & 12 . & \text { No. } & 2 . & \text { Hal. }\end{array}$ http://doi.org/10.22216/jit.2018.v12i2.633

Mayliza, R. (2019). Pengaruh Citra Perusahaan (Corporate Image) Dan Penanganan Keluhan (Complaint Handling) Terhadap Loyalitas Pelanggan (Loyality) Natasha Skin Care Di Kota Padang. https://doi.org/10.17605/OSF.IO/DF9XJ

Nugroho, Bhuono Agung. 2005. Strategi Jitu Memilih Metode Statistik Penelitian dengan SPSS. Yogyakarta: CV. Andi Offset.

Pranata, H. I., \& Mayliza, R. (2019). Pengaruh Komunikasi Pemasaran Terpadu Dan Ekuitas Merek Terhadap Loyalitas Konsumen Pada CV. Laris Motor Cabang Air Haji. https://doi.org/10.31219/osf.io/d9qsu

Purwanto, Joko. 2003. Komunikasi Bisnis. Edisi Ketiga. Jakarta: Erlangga.

Putra, Y. E., \& Aziz, N. (2019). Pengaruh Kualitas Pelayanan Dan Kepuasan Pelanggan Terhadap Loyalitas Nasabah PT. Bank Rakyat Indonesia Cabang Padang. https://doi.org/10.31219/osf.io/hcsw2 
Safitri, R. N., \& Marlius, D. (2017). Penerapan E-Banking Dalam Meningkatkan Jasa Dan Layanan Perbankan Di PT. Bank Rakyat Indonesia Cabang Padang. https://doi.org/10.31227/osf.io/gkv8t

Sugiyono. 2006. Metode Penelitian Bisnis. Bandung: CV. Alfabeta.

Susanti, F. W Ekazaputri. (2018). Service Performance Dan Kepuasan Sebagai Moderating Variabel Terhadap Loyalitas Nasabah Pada PT BPR Labuh Gunung Payakumbuh Jurnal Benefita: Ekonomi Pembangunan Manajemen Bisnis Dan Akuntansi. Volume 3. No. 3. Hal. 433444.http://doi.org/10.22216/jbe.v3i3.3472

Tiza, M. F., \& Susanti, F. (2019). Pengaruh Kualitas Pelayanan Terhadap Kepuasan Pelanggan, Studi kasus pada perusahaan JNE Cabang Padang. https://doi.org/10.31227/osf.io/hx87m

Tjiptono, Fandy. 2000. Perspektif Manajamen dan Pemasaran: Konteporer. Edisi Pertama. Yogyakarta: CV. Andi Offset.

Ulfa, M., \& Mayliza, R. (2019). Pengaruh Kualitas Pelayanan Dan Kepuasan Pelanggan Terhadap Loyalitas Pelanggan PDAM Kota Padang. https://doi.org/10.31219/osf.io/spmgv

Umar Husain. 2000. Riset Pemasaran dan Perilaku Konsumen. Jakarta: PT. Gramedia Pustaka Utama. 